\title{
$I$
}

\section{Theory and Practice,}

\section{Skepticism and Liberalism}

The first half of my title assumes that theory and practice are sufficiently distinct to permit consideration of relationships between them. This assumption is sharply controversial. Melding the two concepts, thinkers in the praxis tradition seem to exclude the possibility of a relationship between them. Other writers might replace my conjunction with a hyphen. There are no practices that are innocent of theory, and all theories presuppose some practice of which they are the, or among the, theories. Theories and practices form pairs not unities, but no instance of either of them can be identified or usefully discussed apart from the instance of the other with which it is paired. Numerous others who have reflected on this topic endorse one or another version of the assumption implicit in my title, and some among them further insist that, properly understood, theory and practice are not only categorically distinct but disjunctive in the sense that theory can play no role in practice.

We have to consider these disagreements. But we do not have to accept the view, which might be suggested by the persistence of the disagreements, that reflection about theory and practice can yield nothing better than a list, perhaps with additions, of stipulations. It is not, I think, tendentious to say that the parties to the controversies I have mentioned are advancing theories about theory and practice. Their theorizing occurs in concepts and makes use of ideas that have not been and almost certainly could not be fully appropriated by any of the past, present, or future contributors to it. There is reason for impatience with the topic of theory and practice, for doubt about the richness of its yield, but there is no reason to think 
that theorizing about it has been or must be merely and hence fruitlessly sectarian.

Similar concerns arise about, and an analogous stance is appropriate concerning, the other elements in my topic-that is, liberalism and the roles of theory and of skepticism in liberal practice. There is a tendency to think that it is with "liberal" and "liberalism" as Hobbes said it was with "good" and "evil" — that is, that these words "are ever used with relation to the person that useth them: there being nothing simply and absolutely so; nor any common rule ... to be taken from the nature of the objects themselves." 1 This tendency of thought commits an exaggeration. Leaving aside the historian's question of just when liberalism emerged, the term is now widely and often vigorously used of ideas and people who hold them, of institutions and policies, of governments and nations. Features prominent in liberalism do give us reason to doubt that we can significantly reduce the diversity of recognizably liberal idioms; certainly there is reason to doubt that we can fully resolve the disputes among self-designated liberals and between them and opponents of liberalism. But this circumstance, commonplace in moral and political philosophy, is hardly reason for dismissing the disputes as spurious or for rejecting the possibility of contributive thinking about them.

There is an easy transition from the foregoing remarks to some preliminary comments concerning skepticism. In its "Academic" and "Pyrrhonian" variants, ${ }^{2}$ respectively, classical general skepticism denied or doubted the possibility of knowledge when "knowledge" was taken to require true, warranted, or at least reasonable beliefs and when the beliefs pertinent to knowledge claims were (or are now usually) taken to consist of integrated sets of general propositions. Let us say, at least provisionally, that such an integrated set of truth-evaluable general propositions is a necessary feature of a theory. On this construal of theory, if we embrace general skepticism we will thereby have answered a main question concerning theory and practice. We will either (I) have to deny that theory can or should play any affirmative role in practice or (2) we

1Thomas Hobbes, Leviathan (Oxford: Basil Blackwell, I955), chap. 6.

2See Richard H. Popkin, The History of Scepticism from Erasmus to Spinoza (Berkeley: University of California Press, I983); Miles Burnyeat, "The Sceptic in His Place and Time," in Philosophy in History, ed. Richard Rorty, J. B. Schneewind, and Quentin Skinner (London: Cambridge University Press, 1984). 


\section{Toward a Liberalism}

will have to say that theory can and should guide practice despite the fact that theories cannot be true (dogmatic skepticism) or that thus far no theories are known to be true (undogmatic skepticism). On the widely received position that true or at least well-warranted answers to questions that practice confronts are the distinctive contribution of theory to practice, the stronger of these two conclusions will follow. Either way, the classical forms of general or doctrinal skepticism seem to require us to reject the idea that theory is necessary to practice, and dogmatic general skepticism requires us to reject the possibility that theory can contribute to the quality of practice.

According to Miles Burnyeat, the Pyrrhonian skeptics of classical antiquity drew very definite practical conclusions from their epistemological doubts and denials. Unable to resolve the issues of moral and political life, they sought "tranquillity" by withdrawing as far as possible from it. ${ }^{3}$ If we regard skepticism as a theory about the possibility of true or contributive theory, their theory of theory and practice had material implications for both theory and practice. As Burnyeat puts it, there was no "insulation" between their theory of theory and practice and their practical judgments. ${ }^{4}$

Burnyeat's account suggests several contrasts with more recent thinking on these topics. As he remarks, a number of modern and contemporary thinkers have reached dogmatically skeptical conclusions about moral and political theory but have put a thick layer of insulation between these conclusions and their thinking about moral and political practice. The "first-order" judgments of moral and political practice are not diminished by the unavailability of true "second-order" theories of the kind traditionally sought by moral and political philosophers. What is increasingly called "commonsense morality" gets along nicely without the assistance of such theories. By denying that practice has any need for such theory, these theories of theory and practice insulate practice from the effects of their own skepticism about theory.

An alternative to (variant of?) the position just sketched is pro-

3Burnyeat, "The Sceptic in His Place and Time," esp. pp. 238-47.

"Ibid., pp. $225 \mathrm{ff}$. There may be a suggestion in Burnyeat's account that the Pyrrhonians adopted skepticism because the suspension of judgment it required implied withdrawal from practical affairs. Their desire for tranquility was primary, their skepticism a justification and protection of it. See esp. Burnyeat, "Can the Skeptic Live His Skepticism?" in The Skeptical Tradition (Berkeley: University of California Press, 1983). 
vided by "antifoundationalism." Instead of saying with the classical skeptics that we cannot establish the truth of theories, or that we do not know whether we can do so, antifoundationalists contend that these epistemological questions are misbegotten and that we should address ourselves to other issues.

In Burnyeat's terms, antifoundationalism might be characterized as putting a double layer of insulation between skepticism and practice. If we adopt this position, we insulate practice not only from (truth-seeking) theory but from that species of theory about theory and practice that is epistemology. Antifoundationalism is a theory about theory and practice which makes not only theory of or about practice but theory about theory and practice (or, more exactly, all theories about theory and practice other than its own) irrelevant to theory and practice.

Wittgenstein's position, which some regard as a version of this view, will concern us below. For now, however, the more striking point is the lack of success of antifoundationalists in their campaign to banish epistemological concerns from moral and political philosophy. Writers of this persuasion may have moved epistemology to the wings of the general philosophical stage, but the concerns traditional to it remain prominent in the domains of morals and politics-perhaps particularly so in the work of self- or widely other-designated liberal thinkers. Leaving aside the early history of liberalism, writers such as Isaiah Berlin, Bruce Ackerman, and a bevy of neo-Kantian thinkers led by John Rawls have rejected utilitarianism and what Rawls call perfectionism and insisted on the ineliminable plurality of conceptions of the good and the good life. The voluntarism, subjectivism, or agent-relativity of these views has provoked vigorous rejoinders from other neo-Kantians (for example, Alan Gewirth) and from neo-Aristotelians (Alasdair MacIntyre), neo-Hegelians (Charles Taylor), and communitarians (Roberto Unger), who claim that moral and political theory can and should provide interpersonally and even interculturally valid specifications of the good. And because some of the liberals who have abandoned the search for a true or a best theory of the good have nevertheless tried to circumscribe pursuit of the conceptions of good that people in fact form with general theories of the right, of justice, and of rights, their efforts have prompted skeptical reactions from a diverse array of writers who deny the possibility, the usability, or the desirability of such theories. Very little of this 
argumentation extends its reach to general skepticism or the "dogmatisms" that have opposed it, and to this extent these thinkers may show the influence of antifoundationalism. But within the domains of concern here, including within and about liberalism, we continue to find a range of views extending from insistent skepticism about the possibilities of true or otherwise contributive theorizing to soaring aspirations for this mode of reflection. If antifoundationalists claim that the epistemological flavor of this work reveals it to be archaic or even reactionary, they must be pressed to defend the certitude with which they advance their own theories of theory and their own theories of theory and practice.

A familiar construal of liberalism, at least of its anglophone variants, gathers the four terms of this essay under the philosophical rubric of empiricism. Most versions of this view posit a hierarchy descending from the general to the particular with epistemology (and sometimes metaphysics) or "first philosophy" governing moral and political theory, which in turn governs moral and political practice. Empiricism correctly determines how we know and what we can and cannot know. Accepting and thinking within these determinations, liberalism as moral and political theory determines how we can know about morals and politics, what we can and cannot, do and do not now know about them. Liberals as moral and political agents act within the determinations of liberalism and attempt to implement their findings and conclusions in moral and political practice.

A slightly modified but forceful articulation of these connections was presented by Bertrand Russell in I947. After identifying Locke as the founder ("so far as the modern world is concerned") of both empiricism and liberalism, Russell asked:

What has theoretical philosophy to say that is relevant to the validity or otherwise of the Liberal outlook? The essence of the Liberal outlook lies not in what opinions are held, but in how they are held; instead of being held dogmatically, they are held tentatively, and with a consciousness that new evidence may at any moment lead to their abandonment. This is the way in which opinions are held in science, as opposed to the way in which they are held in theology.... Science is 


\section{Theory and Practice}

empirical, tentative and undogmatic; all immutable dogma is unscientific. The scientific outlook, accordingly, is the intellectual counterpart of what is, in the practical sphere, the outlook of Liberalism. ${ }^{5}$

As with Locke, Hume, Mill, and numerous others, Russell then identifies empirical science with empiricist philosophy: "The empiricist's theory of knowledge-to which, with some reservations, I adhere-is halfway between dogma and scepticism.... Scientific theories are accepted as useful hypotheses to suggest further research, and as having some element of truth in virtue of which they are able to colligate existing observations; but no sensible person regards them as immutably perfect." 6 His conclusion is that "in our day as in the time of Locke, empiricist Liberalism ... is the only philosophy that can be adopted by a man who, on the one hand, demands some scientific evidence for his beliefs, and, on the other hand, desires human happiness more than the prevalence of this or that party or creed." 7

It may strike some students of liberalism that, as with related accounts from the same period (accounts by "cold war liberals" as they are now, usually with derision, commonly called), Russell modifies understandings that were predominant in the thinking of earlier and some later liberals. As with Russell (and ignoring the transition from "psychological" to "logical" empiricism), many nineteenth- and early twentieth-century liberals regarded empiricism as the philosophical position that best accounted for and regulated natural science; in at least partial contrast with Russell, however, for them the startling successes of science provided the basis for a robust optimism about moral and political matters. Beginning with the sensationalist-associationist psychologists and early utilitarians, at least in part in John Stuart Mill, and continuing among some of the founders of the Liberal party in Great Britain (for example, Graham Wallas), the ambition of many liberal thinkers has been to bring empiricist-based scientific thinking and investigation to bear on social life, expecting thereby to achieve improvements in that realm at least approximating those Newtonian science had made possible in the understanding and control of nature. If

${ }^{5}$ Bertrand Russell, Philosophy and Politics (London: Cambridge University Press, I947), p. 22.

Ibid., p. 24.

7Ibid., p. 27. 


\section{Toward a Liberalism}

present-day liberals are less likely to celebrate science, aspirations of this sort remain alive among them.

This difference between Russell and his predecessors and successors represents a phenomenon-namely, proponents of a single general philosophical position drawing divergent practical inferences from it-which is important to the concerns of this essay. The point for immediate attention, however, is the agreement between Russell and most of his empiricist liberal predecessors concerning the proper relationship between theory and practice.

Empiricism gives an account of our access to reality, and a further account of science as the means of achieving knowledge and truth. Russell puts more stress on the limitations on scientific knowledge than do most of his predecessors (albeit he denies that he does so out of the "sceptical intention" of Hume, who of course anticipated him in this emphasis), but he has only minor reservations concerning the main elements of the empiricist epistemology and metaphysic and no doubt that science, as construed by empiricism, gives us the best knowledge we can have.

Theory, then, is construed as at once plural and hierarchical: that part of theory which comprises epistemology and metaphysics ("theoretical philosophy" in Russell's terms) is the basis of science, and that part of it which is scientific is the basis of the most reliable of all further knowing. Upending the metaphor, epistemology and metaphysics dominate science in that they identify the subject matters and criteria of science and scientific knowledge, and science dominates all other forms of knowing in that conclusions arrived at scientifically and "colligated" in scientific theories are superior to all conclusions lacking these characteristics. Scientific theories are subject to revision in light of new evidence and reasoning, and nonscientific beliefs are subject to revision and rejection in the light of changes in scientific theory. Theory in the sense of theoretical philosophy dominates scientific theory and practice, and scientific theory dominates all nonscientific theory and practice. Insofar as we arrive at scientific theories concerning social and political life, those theories properly dominate social and political practice. Insofar as liberalism incorporates the methods and findings of science, it properly dominates social and political practice.

Thus the more emphatically fallibilist character of Russell's view does not alter the fundamentals of the picture tha this conception gives us of intratheory and theory-practice relationships. The mildly diffident tenor of Russell's empiricist-based liberalism is not due to 
any regard that is owed to practice as against theory. Because his cautions about scientific theory apply even more strongly to beliefs reached nonscientifically, he gives us no general reason or principled ground on which to hesitate about supplanting the latter with genuine instances of the former. Scientific theory is superior not because it helps us to understand practice as it is but because it discovers and orders an independent reality to which practice ought to conform. Theory is relevant to practice not because it is consonant with but an improvement on the understandings and beliefs of practitioners, but because it provides a basis on which to reject and replace the latter. Until such time as scientific theory has supplanted prescientific beliefs and understandings, the contributions of theory will be based on the discrepancies and disjunctions between theory and practice. In political language, empiricist scientists and those who have mastered their theories should rule. They should rule with a due awareness of the limitations of their theories, but equally with awareness of the yet more severe limitations of nonscientific beliefs.

Despite or perhaps because of its long-standing association with liberalism, it is worth asking whether this is a view that liberals should endorse.

\section{II}

We can begin to answer this question, and also give skepticism a more prominent place in the discussion, by recalling that this conception of theory and practice is anything but unique to empiricism or empiricist liberalism. It would be more accurate (albeit an exaggeration) to say that it is the conception that has dominated Western philosophy, certainly moral and political philosophy, from Plato to Jürgen Habermas. Despite the many differences among them, Platonists, Rationalists, Marxists, Critical Theorists, and numerous others have also posited several levels of theory and have had no doubt that theory should dominate practice. ${ }^{8}$

${ }^{8} \mathrm{Cf}$. Anthony Giddens's generalization, advanced in the context of a discussion of the relations between philosophy and social sciences, about social science: "Given their naturalistic presumptions, the proponents of the orthodox consensus assumed that the practical connotations of social science have a 'technological' form. The social sciences correct false beliefs that agents have about social activity or institutions. As we get to know the social world better, just as in the case of the natural world, we are in a position to change it." Anthony Giddens, Social Theory and Modern Sociology (Stanford: Stanford University Press, 1987), pp. 70-7I. 


\section{Toward a Liberalism}

Despite this commonality, empiricist liberals have regarded the views just mentioned as the deadly enemies of liberalism. This hostility is of course due in part to their conviction that theories not resulting from empirical inquiry as empiricism construes and directs it will almost assuredly-happenstance aside-be false. For this and other reasons they have viewed such theories and the theorizing that produces them as dangerous. Echoing Karl Popper, Russell insists that Platonism, Hegelian idealism, and Marxism are like religions not only in lacking any basis in evidence and reason but in that they engender fanaticism. Unburdened by the need to demonstrate the fit between their conclusions and observed fact, their proponents have afflicted us with grandiose moral and political visions and with futile but destructive attempts to enact those visions in moral and political practice.

Many philosophers, empiricists and otherwise, have thought that empiricism entails or at least engenders philosophical skepticism. Some of those favorable to it have argued that it is this among its features (whether emphasized or even clearly recognized by this or that liberal theorist) that immunizes empiricist liberalism against the virulent diseases of thought and conduct that Popper and Russell attack. The unique advantages of empiricist-based liberalism result from the combination of the scientifically warranted certitude it yields on some questions and its philosophically grounded doubt on all others. Although emphasized much more strongly by some liberals than by others (perhaps most strongly by the "cold war liberals"), this combination has been present in empiricism not only from Locke on but from its beginnings in the thought of Sextus Empiricus.

For reasons already mentioned, however, this feature of empiricist liberalism, rather than allaying the apprehensions generated, for liberals, by the conception of theory-practice relationships in question, puts empiricist liberalism in conflict with itself. On the one hand, if empiricism entails a robust skepticism it will not support so much as Russell's mildly chastened conception of theory-practice relationships (to say nothing of the more enthusiastic liberalisms that we might now associate with phrases like "the best and the brightest"). The possibility of "scientific theory," and hence also the expectation that such theory could properly rule practice, would be narrowly circumscribed if not eliminated. Hume's more potent skepticism would not be a matter of this or that theorist's personal 
"intentions"; it would be a logically necessary consequence of empiricist epistemology. On the other hand, the logical implications of empiricism would not prevent empiricist liberals from "insulating" their practical thinking and acting from their skepticism, maintaining their conception of theory and practice, and going right ahead with their moral and political projects.

III

Later I consider the role of skepticism in conceptions of theory and practice that are sharply divergent from all of those mentioned thus far, conceptions that might provide an alternative orientation to liberalism. Before taking this more affirmative turn, however, we should recognize affinities between my remarks about empiricist liberalism and the views of leading antiliberal writers. Sharp criticism of empiricism is pervasive in modern philosophy. ${ }^{9}$ Influential writers have accepted the connection between empiricism and liberalism and have argued that the defects of the former vitiate the latter. Whatever we may think about Hegel's relation to liberalism, his is a major refutation of empiricism: neo-Hegelians have accepted that refutation and drawn the inference about liberalism that I just stated. (Charles Taylor and perhaps Roberto Unger are contemporary examples.) Marx and many Marxists take parallel positions, and analogous patterns of argumentation can be found in Nietzsche, in Heidegger, and in neo-Aristotelian views such as those advanced by Alasdair Macintyre. The several elements that constitute empiricist liberalism-the atomic entities that constitute all matter; the logically unrelated sensations and percepts through which we experience those entities; the passive, structureless minds in which our sensations and perceptions associate; above all, the isolated, self-subsistent "individuals" standing in no more than radically contingent but usually adversarial relations with one another which we as persons are said to be-are all dismissed as, in F. H. Bradley's frequently quoted phrase, "delusions of theory."

For these critics, then, as a philosophical matter empiricism and

${ }^{9}$ The essays in ibid. provide one of a number of recent surveys of these developments, Giddens's account being valuable in the present context because of his concern with the relationships among "first" or "theoretical" philosophy, social theory, and social and political practice. 


\section{Toward a Liberalism}

liberalism can only be scorned and dismissed. Of course they recognize that liberals have induced many to think and act.as if their philosophical hallucinations are true. Turning Russell's rhetorical move back against liberal theorists, they pay the latter the same "compliment" that Russell accorded proponents of religions and of political theologies, namely, allowing that they have successfully propagated their false and destructive creeds. But sharing as they do the fundaments of Russell's conception of theory as properly ruling practice, these critics nevertheless think what he thought about Christianity, Marxism, and fascism-namely, that their refutations of empiricism ought to discredit liberalism.

As a historical matter, this form of antiliberal argumentation overlooks liberal theorists-such as Kant and various neo-Kantians, Green and his residually idealist successors-who are among the most determined and effective critics of empiricism. In some cases, moreover, neo-Kantian and other at least vestigially idealist liberalisms, although sponsoring conceptions of theory-practice relations that are substantially analogous to those I have been discussing up to now, have entered important modifications in those conceptions. In company with numerous antiliberal praxis theorists, they have sustained the idea that theory can and should improve practice in various significant ways but rejected the empiricist view that theorists properly go about improving practice by displacing practitioner understandings. Theory might modify practice, might over time contribute to a transformation of practice, but it cannot do so à la empiricism.

To this extent, these alternative forms of liberalism open up the question that is most important for present purposes. Insofar as we reject (as both doctrinal skeptics and antifoundationalists do), or qualify (as some alleged skeptics and some alleged antifoundationalists have done and as I attempt to do below), the conception of theory and practice I have been discussing, we may be able to: (a) recognize that empiricism has often been associated with liberalism; (b) reject empiricism; but (c) embrace liberalism. The liberalism that we embrace, however, will have to involve a quite different conception of theory and practice.

I discuss some recent formulations of liberalism that are arguably idealist in philosophical orientation later in this essay. But if I am correct that these views partly endorse the understanding of theory as dominating practice, considering them will not provide a genuine 
alternative to the conceptions of that relationship which I have thus far discussed. For this reason, and because empiricism and idealism are widely thought to exhaust the array of philosophically informed and motivated versions of liberalism, I first look outside of liberalism for different ways to assemble the elements of this essay. In making this sojourn abroad, however, we will have to take seriously the possibility that "first philosophy" of any sort has little more than prophylactic or perhaps antidotal value for either moral and political theory or moral and political practice.

\section{IV}

Let us consider views, those of Michael Oakeshott and the later Wittgenstein, which reject not only empiricism but all arguments to the effect that theory can or should direct, guide, or in any way contribute to practice. ${ }^{10}$

According to Oakeshott's theory of theory and practice, theory is categorially distinct from and hence categorically irrelevant to practice. Attempts by "theoreticians," "rationalists," and other "impudent mountebanks" 11 to deny this and to impose their abstractions on practice are double failures: they abandon theorizing in the only distinct and defensible sense of the term and they distort and damage the practices into which they intrude.

The basis for this position is laid in Experience and Its Modes. ${ }^{12}$ In Part II of this unduly neglected work, Oakeshott rejects as selfcontradictory the several elements of empiricism mentioned above. The key distinctions on which it depends, between subject and object, among sensation, perception, and intuition on the one hand and between them and thought or judgment on the other, are

${ }^{10}$ Wendell John Coats, Jr., has argued persuasively that Oakeshott's thought provides a distinctively coherent formulation of a liberal view. With few and minor exceptions, I agree with his analysis of Oakeshott's thought and further agree that the elements Coats emphasizes are central to a form of liberalism. As Coats recognizes, however, Oakeshott himself would hardly condone this classification-or appropriation-of his thinking. See "Michael Oakeshott as Liberal Theorist," Canadian Journal of Political Science I8 (December 1 985):773-87.

${ }^{11}$ Michael Oakeshott, On Human Conduct (Oxford: Clarendon Press, I 975), p. 30 .

12Michael Oakeshott, Experience and Its Modes (Cambridge: University of Cambridge Press, 1933). 
"abstractions" from the "world of ideas" which is experience as a "concrete whole," abstractions that depend for their intelligibility on the whole of which they are a part and from which they have been abstracted. In denying this, in claiming that "things" or "individuals" are self-subsistent and that sensations and perceptions stand apart from one another and hence from thinking, empiricism denies presuppositions of what it attempts to affirm.

In privileging these abstractions, empiricism also abandons philosophy and philosophizing. "It is our business in philosophy to avoid abstractions." Uniquely, philosophical experience is "experience without presupposition, reservation, arrest or modification." As distinct from all other thinking, philosophy seeks experience that is "critical throughout," that pursues the coherence of the world of ideas until it provides "the evidence of its own completeness" in the sense that all of the suppositions of and all of the connections among the ideas that constitute that world (the world) have been identified and purged of incoherence. ${ }^{13}$

The notion of a fully coherent, fully concrete world of ideas, and of philosophical knowledge as complete knowledge of that world, although the only notion that is entirely free from abstractness, "is necessarily fleeting and elusive." 14 But it is also indispensable in the sense of logically necessary to all thinking, and its unremitting pursuit is the defining characteristic of philosophy. Coherence is the criterion of intelligibility and hence of truth, of reality, of all that is "satisfactory" in experience. It is implicit in the partial coherence of all that is intelligible; it presents itself more distinctly as the philosopher notices unappreciated suppositions and attempts to rectify disjunctions and inconsistencies.

For Oakeshott, then, philosophy does not probe beneath, behind, or outside of pre-, non-, or extraphilosophical thought. There is one world, the world of ideas. In this respect, and notwithstanding the uniqueness of its objectives, philosophical thinking is continuous with, inseparable from, all other thinking. Rather than correcting nonphilosophical thinking by reference to philosophical discoveries brought back like gifts from some other realm, it explicates the world of ideas.

In his later On Human Conduct and related essays, Oakeshott narrows his focus from philosophizing concerning experience as a

13Ibid., pp. 9, 2.

14Ibid., p. 3 . 
whole to what he calls "theorizing" conduct inter-homines. Confined as it is to seeking the coherence of the "mode of experience" he earlier called the "practical," this activity allows of being "arrested" and "abstract" in ways that philosophizing as analyzed in Experience and Its Modes has to suffer but cannot endorse. In respect, however, to their implications for empiricist liberalism and other doctrines that promote the dominance of theory over practice, philosophizing and theorizing are as one.

Both theorists and practitioners of human conduct seek coherence in thought and action. They both "begin" (in a logical not a temporal sense) by "recognizing" various "goings-on" as having certain distinguishing characteristics, "identify" them as consisting of compositions of characteristics gathered under "ideal characters," and seek to extend further the intelligibility of their experience by "mapping" the relationships among the latter. To the extent that they succeed, they attain to a "platform of conditional understanding" that is a "considerable advance" on the coherence among the mere recognitions with which they "began." 15 Theorists then press on to an activity in which, for reasons we will consider below, practitioners cannot engage-that is, identifying and "interrogating" the "postulates" of platforms of understanding. But here too theorists are dependent on practitioners because the postulates they interrogate and theorize are postulates of the ideas and understandings of practitioners. In this and other ways, this understanding of theorizing discredits the conceptions of theory and practice discussed above. The ideas common to those conceptions-namely, leaving practice wholly or partly behind, discovering a truth or a reality independent of it, and bringing that truth back as a substitute for or corrective to practice-are "delusions of theory." There is no truth or reality apart from practice for theorists to theorize.

As we have seen, Oakeshott rejects much more than the doctrine that philosophy and theory can and should supplant and dominate practice. Despite the views I have summarized, he holds that philosophy and theory are categorially distinct from and categorically irrelevant to practice. His reasons for this conclusion, surprising and puzzling given his insistence on the continuities between theory and practice, will be assessed below. But first let us consider another formulation with a strongly analogous combination of features.

${ }^{15}$ Oakeshott, On Human Conduct, p. 6. It should be emphasized that Oakeshott's account is not to be construed as a chronicle, as identifying temporally calibrated sequences through which these steps pass. 
Wittgenstein rejects Oakeshott's idea that the unique purpose of philosophy is to discern and examine something that can be of no interest to nonphilosophers, that is, the world of ideas as a concrete whole or the postulates of their own thinking and acting. "Philosophy simply puts everything before us, and neither explains nor deduces anything.- Since everything lies open to view, there is nothing to explain. For what is hidden, for example, is of no interest to us." "If one tried to advance theses in philosophy, it would never be possible to question them, because everyone would agree to them." "And we may not advance any kind of theory. There must not be anything hypothetical in our considerations. We must do away with all explanation, and description alone must take its place.... The problems are solved, not by giving new information, but by arranging what we have always known." "Philosophy may in no way interfere with the actual use of language; it can in the end only describe it. For it cannot give it any foundation either. It leaves everything as it is." 16

We might treat the foregoing passages as a radical extension, an extension to "everything," of Oakeshott's views about theory and practice. Oakeshott argues that philosophy and theory may not interfere with practice, that they leave practice as it is. But he also posits further, categorially distinct, kinds of reflection that are exclusively the province of philosophy and theory. Rejecting (albeit not refuting) the idealist notion of a single, entirely coherent world of ideas that lies behind Oakeshott's conception, Wittgenstein denies that philosophy has any distinct subject matter. Philosophy is continuous with all other thinking in respects yet deeper than those Oakeshott insists on.

It is tempting to go further and say that for Wittgenstein "everything" is what Oakeshott calls practice, that none of us is other than a more or less adept practitioner of various practices or activities, and hence that there is no distinct role for philosophy to play, no special purpose for "it" to pursue.

Although not simply mistaken, this further inference fails to take account of features of Wittgenstein's thinking which are especially pertinent here. Despite the passages I quoted above, Wittgenstein made investigations he called "philosophical" and his writings in-

16Ludwig Wittgenstein, Philosophical Investigations (New York: Macmillan, I953), I, I 26, I 28, I09, I 24. 
clude various remarks about the distinctive characteristics and objectives of philosophical work. We cannot substitute these passages for attention to the detail of his investigations, but several of his more programmatic statements will repay immediate notice.

"The philosopher's treatment of a question is like the treatment of an illness." "There is not $a$ philosophical method, though there are indeed methods, like different therapies." What illnesses does the Wittgensteinian philosopher treat; what are the maladies to which philosophers administer their various therapies? "Naming," he says, sometimes "appears as a queer connexion of a word with an object.-And you really get such a queer connexion when the philosopher tries to bring out the relation between name and thing by staring at an object in from of him and repeating a name or even the word 'this' innumerable times. For philosophical problems arise when language goes on holiday." 17 Captivated by a picture or ideal of what must be the case, the philosopher fails to attend closely to language actually at work in thought and action. Removing concepts from the contexts or circumstances that are integral to their meanings, in which they are "in order," philosophers perplex themselves with paradoxes of their own creation. The therapies Wittgenstein provides vary from case to case, but they all involve dissolving the picture or disqualifying the ideal by bringing the concepts in which they are expressed back to the settings in which they are unproblematic.

We might say that Oakeshott and Wittgenstein treat practice as "theory-like" and practicing as a form of theorizing. Among the main elements of practice are concepts, ideas, beliefs, and the like. As with the components of any formation that deserves the name of a theory, these elements make up ensembles each of which has a more or less definite and discernible pattern or order. These patterns are produced, maintained, and altered by the practitioners who think and act within and about them. As with good theorists, adept practitioners understand the patterns of the various ensembles (ideal characters, language games) in which they think and act and

17Ibid., I, 25 5, I 33, 38. Cf. ibid., 52, I 3 I, I94, 295, 393, 520, 588-90. 


\section{Toward a Liberalism}

perhaps something of the larger patterns (forms of life, traditions and practices) formed by constellations of ensembles. Although necessarily accepting much of what they have come to understand, their thought and action may enhance, diminish, or otherwise change the existing patterning by altering or rearranging some of its elements. Like unaccomplished theorists, less adept practitioners may fall into and create confusion.

Characterizing their views in this way underlines some of Oakeshott's and Wittgenstein's objections to the conceptions of theory and practice promoted by empiricism and a variety of other doctrines. To say that practice is theorylike and that "practicing" is like theorizing is to affirm that they have properties such as intelligibility, internal consistency, and coherence; that is, that all practices and practicing have at least some of the properties that theorists with overweening ambitions say practices acquire only after they have been remade by Scientific, Rationalist, or other philosophizing (remade to meet criteria not internal to them prior to the successful intervention of the theorist).

The same characterization, however, seems to open up a possibility that Oakeshott insistently denies and that Wittgenstein occasionally seems to deny and more frequently disparages-namely, that theory might make distinctive contributions to practice. If philosophy or theory are inseparable from and continuous with practice in the ways I have been discussing, why can't theory contribute to practice as it pursues its distinctive activities and purposes, in the course of conducting those pursuits? Do not the same considerations that discredit empiricism and related views suggest that success in enhancing the coherence of the world of ideas and ministering to confusions in thought would contribute something of at least modest value to practice? Might we not go further and say that the views sketched in Section III of this chapter articulate a praxis conception of theory and practice and hence make theory not only valuable but integral to practice? If there is an objection to the idea that theory can contribute to practice, it might be the one to which I adverted at the outset, namely, that there is no clear distinction between them and hence no basis for saying that "the one" can or cannot assist "the other." It is now time to assess Oakeshott's and Wittgenstein's reasons for rejecting these inferences.

Beyond passages already quoted, such as "philosophy leaves everything as it is" (and leaving aside his pessimism about the likeli- 
hood that his thinking would be so much as understood), Wittgenstein frequently takes a derisive attitude toward the philosophical therapies he performs. Like a medical doctor curing diseases that other doctors have inflicted on themselves by bad medical practice, his recognition that his patients are genuinely in distress is not enough to suppress a certain disdain for them and for their illnesses. In these passages philosophizing presents a dismal appearance. "What we are destroying is nothing but houses of cards and we are clearing up the ground of language on which they stand." "The results of philosophy are the uncovering of one or another piece of plain nonsense." "My aim is: to teach you to pass from a piece of disguised nonsense to something that is patent nonsense." "A whole cloud of philosophy consensed into a drop of grammar." 18

Better, it might seem, if philosophy had never made an appearance.

By contrast with Wittgenstein's occasional and enigmatic remarks on this subject, Oakeshott argues explicitly and at length that philosophy and theory are categorically irrelevant to practice. Because his arguments will help us to identify the combination of limitations on and possibilities for contributions of theory to practice, they are worth considering in some detail. I concentrate on his discussion of theorizing in On Human Conduct, taking up with the "platforms of conditional understanding" to which I earlier brought my discussion of his theory of theory and practice.

For practitioners, the identifications assembled to form these platforms are "diagnoses" and "verdicts." As these terms imply, they are invitations to action. "The identities disclosed in 'this is a case of the measles,' 'that is a bank robbery,' ... are understood [by practitioners] to prescribe utterances such as 'isolate the patient,' 'sound the alarm,' ... or performances that correspond to these utterances." "An utterance which provokes laughter is an utterance diagnosed as a "joke." "19 These identifications can be meaningful only to the extent that they are part of a more or less coherent set of understandings; but for practitioners their meaning is, in J. L. Austin's sense, exclusively perlocutionary; understanding them is knowing how to perform in response to the diagnoses and verdicts they issue.

18Ibid., I, I I 8, I I9, 464; II, p. 222.

${ }^{19}$ Oakeshott, On Human Conduct, pp. 7-8. 


\section{Toward a Liberalism}

By contrast, the theorist (as with the philosopher of Experience and Its Modes) must decline the invitation to action and accept another that the practitioner cannot entertain, namely, to question further the ideal characters and the platforms of understanding they compose. In order to act on verdicts, the practitioner must accept them and hence also the set of identifications that compose the platforms of understanding from which they issue. The practitioner is, and as practitioner must remain, "in the prison of his current understanding." 20

It is from this prison that the theorist "seeks release," release that can be obtained only by understanding the identities "in terms of their postulates." As Odysseus did with the songs of other Sirens, theorists must close their ears to the invitations to action accepted by practitioners and set out instead on an "unconditional adventure in which every achievement of understanding is an invitation to investigate itself and where the reports a theorist makes to himself are interim triumphs of temerity over scruple." For the theorist, platforms of understanding are not instruments to be used in action but objects of further interrogation. "The irony of all theorizing is its propensity to generate, not an understanding, but a not-yetunderstood." 21

Thus far, theory is held apart in order to protect it from the distractions of practical activity. Theorizing, however, is not itself unconditional, and just as philosophy in the fullest sense cannot hope to achieve complete coherence, theorizing has no prospect of arriving at a "terminus in an unconditional theorem." As with the actions of practitioners, theorizing is and must always be from a platform of understanding parts of which the theorist cannot now be interrogating. As Wittgenstein says, to think about this, the theorist must accept much else. What distinguishes the theorist from the practitioner, rather, is the determination of the former to be "perpetually en voyage," to regard success in delineating the postulates of previous understandings as reason for neither action nor rest but for questioning the conditions of that success. ${ }^{22}$ This labor is not Sisyphean in the sense of having endlessly to do again exactly what was already done; nor is it interminable for the reason that empiricists sometimes suggest-namely, that we can never be

20Ibid., p. 9.

21Ibid., pp. 8, I I.

22Ibid., p. II. 
certain we have correctly identified all of the "facts" that need to be "colligated" by the scientific theorist. Theorizing can be stopped but never finished because every stopping place involves suppositions that require interrogation.

The illusion that the theorist has achieved an unconditioned theorem is one source of the mistaken and "impudent" view that theory can and should govern practice. Convincing themselves that they have achieved "an unconditional understanding of the world in terms of its postulates," Platonists, Rationalists, Marxists, and even some empiricists (for example, Bentham) dismiss the conditional understandings of practitioners as "worthless nescience" and promote their own self-admired constructions as "a complete substitute for," as "a definitive understanding and language to supersede and to take the place of all other understandings and languages." In addition to being a self-congratulatory philosophical fantasy, this species of presumption badly underestimates those whose thought and action it dismisses. Practitioners "are not at all inadequately equipped for understanding and dealing with the world in which they live." There are "expert map-makers and adept diagnosticians" among them and their unconcern for the conditional character of their identifications does not diminish their prowess as practitioners. ${ }^{23}$ Rather, the theorist's theorems about postulates are irrelevant to conduct and cannot possibly substitute for or improve on the diagnoses and verdicts of practitioners.

Holding as it does for all theorems not merely for supposedly unconditional ones, the last claim is the most general and the most important for our purposes. Platonists, Marxists, and self-described scientific empiricists are distinctive in their readiness to discard practitioner understandings, but they are not the only theorists who desert their calling and become "theoreticians"-imposters who claim that their abstractions entitle them to govern practice. "This deplorable character has no respectable occupation. In virtue of being a theorist he purports to be concerned with the postulates of conduct, but he mistakes these postulates for principles from which 'correct' performances may be deduced or somehow elicited. $\mathrm{He}$ understands it to be his business to umpire conduct, certifying performances ... [as] 'correct' [or] ... 'incorrect' inferences from the theorems of an alleged understanding of conduct in terms of its conditions. But since such theorems are incapable of specifying 23Ibid., pp. 26, 29, 29-30. 


\section{Toward a Liberalism}

performance, the engagement of the 'theoretician' is a spurious engagement in conduct itself, an undertaking to direct the activities of map-makers, diagnosticians and agents by systematic deception. $\mathrm{He}$ is a fraudulent tutor; and the certificates he issues are counterfeit, acceptable only by those who share his belief in the truth of his theorems and share also his delusions about their character." 24 In their futile attempts to close the gap between the postulates that theorists discern and interrogate and the verdicts and diagnoses of practitioners, theoreticians commit "the most fatal of all errors," ignoratio elenchi; they fall victim to "the most insidious and crippling of all forms of error-irrelevance." 25

These last passages align Oakeshott with views about "practical reasoning" and "judgment" which go back at least to Aristotle, are closely akin to Wittgenstein's discussions of rule following and (more generally) "knowing how to go on," and embody what is most important in both Oakeshott's and Wittgenstein's views concerning the limits of philosophy and theory as they understand them. I return to these views by way of concluding this essay. But first we must see why the arguments just considered do not support the restrictive conclusions that seem to be implied by some of Wittgenstein's remarks and that Oakeshott insistently draws.

As with the inference that philosophy is indistinguishable from thinking sans phrase, the conclusion that it would have been better if we had avoided it altogether exaggerates an element that was genuinely a part of Wittgenstein's thinking. We should note a sense in which even his most disdainful responses to the work of other philosophers serve to modify his assertion that his own philosophizing "leaves everything as it is." In curing their diseases of thought, Wittgenstein returns them and perhaps us to the status quo ante philosophicum, restores the health and good order that their misguided thinking had corrupted. And if one thinks, as Oakeshott sometimes seems to think about theoreticians, that philosophers can transmit their viruses to nonphilosophers, such immunization of thought, the practice of such preventive philosophical medicine, would deserve higher regard than he appears to accord it.

This modification takes on substantially greater significance when we see that there are wider grounds for thinking that the illnesses

24Ibid., pp. 26-27.

${ }^{25}$ Oakeshott, Experience and Its Modes, p. 5. 
to which philosophers fall victim are not purely "iratrogenic" in the sense of resulting exclusively from bad philosophical practice. Whereas Oakeshott typically writes as if the only (if any) practical contribution of philosophy and theory is to cleanse practice of the pollutants discharged by theoreticians, Wittgenstein thinks that philosophers are especially prone to diseases to which we are all susceptible. "Philosophy [as Wittgenstein himself practices it] is a battle against the bewitchment of our intelligence by means of language." "The problems arising through a misinterpretation of our forms of language have the character of depth. They are deep disquietudes; their roots are as deep in us as the forms of our language and their significance is as great as the importance of our language." Language (langue) is in order as it is in the sense that there is no ideal language and no extralinguistic reality by comparison with which the languages we have can be judged, corrected, or improved. But speech (parole) and thought are often not in order. "We do not command a clear view of our use of our words." "The aspects of things that are most important for us are hidden because of their simplicity and familiarity. (One is unable to notice something-because it is always before one's eyes.) ... We fail to be struck by what, once seen, is most striking and powerful."'26

Those who engage in what "used to be called 'philosophy", are distinctively but not uniquely susceptible to these difficulties. The "forms of language" are deep in us all, and the "hiddenness" of the familiar makes it difficult for any of us to see those forms clearly. It is not only in doing philosophy that we become "entangled in our own rules" and fall into the kinds of contradictions that lead us to say things such as "I didn't mean it like that." "The civil status of a contradiction, or its status in civil life: there is the philosophical problem."27

An implication of these views, writ large in Wittgenstein's philosophical practice, is that philosophical therapy cannot be brisk. As their counterparts in psychoanalytic therapy are wont to claim as their achievement, philosophical therapists must appreciate the depth, the complexity, and the power of the disquietudes to which they minister. "Philosophy unties knots in our thinking; hence its result must be simple, but philosophizing has to be as complicated

26Wittgenstein, Philosophical Investigations, I, I09, I I I, I 22, I 29.

27Ibid., I 25. 
as the knots it unties." "In philosophizing we may not terminate a disease of thought. It must run its natural course, and slow cure is all important."28

Contrary to interpreters who dismiss Wittgenstein as some sort of Panglossian or apologist, these are not the remarks of a thinker complacent about the subject matters of his reflections or disposed to diminish the importance of his thinking. To untie the knots in our thinking, to cure the diseases of thought from which we suffer, to achieve a clearer view of our practices and activities, these accomplishments, even if modest by comparison with the ambitions of traditional philosophers, would be far from negligible. ${ }^{29}$

Returning to the more difficult matter of Oakeshott's arguments, I have no disposition to deny the significance of his paired distinctions between the postulates and, for example, the principles of a practice and between thinking in and thinking about postulates. These distinctions are less clear-cut than he supposes, but they do mark important differences such as between doing historiography and doing history, between the philosophy of science and science, and between the primarily metatheoretical enterprise of this essay and the more usual (or at least the more widely proclaimed) purposes of both political theorists and political practitioners.

Developing this perspective a bit further will help us to appreciate both the somewhat anomalous character of the programmatic Oakeshottian and Wittgensteinian views about philosophy-practice and theory-practice relations and the admittedly circumscribed but nevertheless larger possibilities for theory that are implicit in the views I have been discussing.

Assuming that we have gotten in hand serviceable distinctions

28Ludwig Wittgenstein, Zettel (Oxford: Basil Blackwell, I 967), 452, 382.

29It is of course true that Wittgenstein was deeply pessimistic about the prospects of success in these endeavors. But deep pessimism does not overtake us in respect to the trivial or the merely foolish. See especially the Preface to Philosophical Investigations. It might be added that there is at least an analogy between Wittgenstein's conception of philosophy as therapy and conceptions of genealogists such as Nietzsche and Foucault. Wittgenstein's work does not have an explicit historical component and it is concerned primarily with the ideational and conceptual rather than the institutional dimensions of practice. The first point is important, marking as it does Wittgenstein's rejection of all forms of historicism. The second is less so, the distinction itself being difficult to draw clearly on Wittgenstein's views. But I introduce the comparison to further discredit the view that Wittgenstein's work is somehow complacent or Panglossian. That he thinks the diseases he treats are in principle curable does not alter his view that they are deep and serious afflictions. 
between the elements of practice about which practitioners think and act and the postulates of those elements (neither an innocent nor an unproblematic assumption), it may be true that one and the same person cannot simultaneously think within and think about those postulates. And it is certainly false that self-conscious thought about postulates is necessary to thinking and acting within themalbeit it is doubtful, as Oakeshott says, that anyone could think about a set of postulates that they had never thought within. Oakeshott himself denies the possibility of a life given exclusively to philosophy or to theory. ${ }^{30}$ Persons who are practitioners may never think about the postulates of their practices, but persons who are theorists are sometimes practitioners and therefore must sometimes think within the postulates of practices. Moreover, the world of ideas that is experience is a whole; however differentiated and complex it may be internally, philosopher-theorists must work on the assumption that every element of it connects to and can be made to cohere with every other.

The perspective just described is the one from which Oakeshott the philosopher-theorist identifies and distinguishes modes of experience such as history, science, and practice, ${ }^{31}$ "orders of inquiry" such as the procedural and the processual, the "idioms of inquiry" that form the basis of the several conventional academic disciplines, ${ }^{32}$ and the platforms of conditional understanding discussed above. It is also at least implicitly the perspective from which Oakeshott makes his distinctions between morality as a vernacular and an authoritative specification of ends; between a civil society and an enterprise association; between authority and power; between law (lex) and other types of rules; and between politics and (roughly) administration. ${ }^{33}$ The perspective does not invalidate or diminish the importance of these distinctions: the world of ideas is a whole, but it is a whole consisting of parts that must be distinguished and related. Rather, the perspective enables the distinctions, gives the philosopher-theorist a standpoint from which to draw them. If the distinctions are drawn in a manner that enhances coherence, then so far from committing category mistakes à la the theoretician, the philosopher-theorist not only exposes the misun-

30Oakeshott, Experience and Its Modes, p. 3.

31Ibid., chaps. 3-4.

32Oakeshott, On Human Conduct, pp. 13-17.

33Ibid., esp. pp. 6Iff.; essay II; pp. I27-38, I6I-84. 


\section{Toward a Liberalism}

derstandings of theoreticians (and to that degree protects practice and practitioners against them) but enhances the satisfactoriness of experience.

Oakeshott's claim that philosophy and theory are categorically irrelevant to practice, and - though less clearly so-Wittgenstein's argument that philosophy can be no more than therapeutic, are most convincing when construed as directed against positions that are incoherent because they deny conditions necessary to their own intelligible formulation. In denying what I have called the theorylike character of practice, in arguing that practice will acquire this characteristic only after it has been remade by theory, proponents of these positions in effect claim that there can be and is thought and action (experience) which are intelligible or meaningful despite the absence of order, pattern, or integration among their elements. They claim that they understand practice, understand it well enough to identify its defects and to determine how those defects should be remedied. They may even allow that in some degree practitioners of unreformed practices understand themselves and one another. But they characterize practice and practitioners in ways that on Oakeshottian and Wittgensteinian views make understanding impossible.

The anomaly is that, despite these views about practice, in their most programmatic statements about philosophy, theory, and practice, Wittgenstein and especially Oakeshott insist on distinctions that deny to philosophy and theory the very possibilities for contributing to practice that their views about practice open up.

Philosophers, theorists, and practitioners are and must be alike in that they pursue and to some considerable extent achieve coherence and intelligibility, seek to and to some considerable extent succeed in eliminating inconsistency, disjunction, and the like from their thinking. But (bracketing the Oakeshottian idea of complete coherence) coherence, intelligibility, meaningfulness, and the like are matters of greater and lesser, not all or none, and it is undeniable that much thought and action succeeds by various criteria despite the presence in them of inconsistency, confusion, and misunderstanding that are unnoticed, unresolved, and even deliberately introduced and maintained.

Realizing this, we can draw valuable but less than categorial distinctions among philosophy, theory, and practice. Oakeshottian philosophers differ from theorists (Wittgenstein does not make this 
distinction), who differ from practitioners, not in some notional sense of kind but in the centrality they respectively accord to criteria such as coherence and integration and more particularly the singlemindedness with which they pursue these rather than partly complementary but sometimes competing objectives. Remembering that all philosophers and theorists are also sometimes practitioners, we might say that there is something of a division in the labor of achieving and sustaining what Oakeshott calls satisfactoriness in experience. Philosophers and theorists are specialists in detecting confusions and other maladies in the "theory" implicit in practice; practitioners specialize in acting on the invitations that theory extends. To the extent that philosophers and theorists identify and help to "cure" diseases of thought, they may contribute something that is-by standards practitioners also at least implicitly acceptof value to practice. Although Oakeshott officially denies and Wittgenstein frequently diminishes the idea of such contributions of theory to practice, their respective theories of theory and practice provide reasons for entertaining that idea.

\section{VI}

Are these possibilities worth pursuing? Are they and the views from which they emerge more consonant with or appropriate to liberalism than those discussed earlier in this essay? Does skepticism play any role in the combination of possibilities for and limitations on moral and political theory which are suggested by Oakeshott and Wittgenstein?

The last of these questions is the easiest and answering it will be of some help in addressing the first two. Both Oakeshott and Wittgenstein can be described as skeptical in the nondoctrinal, perhaps dispositional sense of tending to look with suspicion on claims and arguments, especially those advanced by philosophers. (It is probably also accurate to say that they are both, perhaps congenitally, pessimists.) But neither of them accepts the view that warranted belief is impossible or cannot be known to be possible. Oakeshott has no doubt that he has refuted empiricism, rationalism, and indeed doctrinal skepticism itself, has demonstrated that they are incoherent and hence false. Again, while he has no hope of achieving the fully coherent world of ideas that philosophy seeks, he is 


\section{Toward a Liberalism}

entirely confident that this is the proper objective of philosophy. This means that philosophers and theorists can never rest content, must always seek to enlarge the coherence of the world of ideas. But it does not impugn their partial achievements. Most important here, it does not impugn the claims of practitioners. By the criteria appropriate to their activities, those claims can be and often are adequately warranted. Wittgenstein does not refute empiricism, idealism, or skepticism, but rather dissolves them by showing that they fail to give intelligible formulations to key concepts such as "truth" and "knowledge," "certainty" and "doubt." By the criteria established in the language-games and forms of life in which they are made, claims to knowledge, certainty, validity, and the like, claims to have "gone on" or to be going on correctly in various activities, are sometimes justified, sometimes not. Claims to and demands for some further, some philosophically superstrong justification or disjustification, are misguided, are chief sources of "diseased" thinking.

Moving toward liberalism, let us look at these aspects of Oakeshott's and Wittgenstein's thinking in the perspective of the concern of Russell and other liberals to erect barriers to theory-driven utopianism, arrogance, and fanaticism. Earlier I argued that empiricist liberalism is at odds with itself in the following respect: its skepticism and fallibilism, which it claims expose dogmatism and block unwarranted intrusions into practice, conflict with its equally deeply grounded ambition to replace erroneous practice with scientific truth. Because this conflict is internal to the theory, its resolution is left to the "intentions" of this or that soi-disant liberal, to the determination liberals bring to "insulating" their scientific faith from their skepticism or vice versa.

Empiricist liberalism (and perhaps other doctrines that promote or at least entertain the possibility of the dominance of theory over practice) seeks to get beneath, above, outside of language, convention, practice. By contrast, for Wittgenstein there is no beneath, no outside. "Our acting is at the bottom of our language games."34 "There is no outside; outside you cannot breathe." 35 For Oakeshott there is one world, the world of ideas. Wittgensteinian and Oakeshottian theory excludes as misconceived or incoherent this empiricist and all similar projects. Philosophers and theoreticians who

${ }^{34}$ Ludwig Wittgenstein, On Certainty (Oxford: Basil Blackwell, I969), 204.

${ }^{35}$ Wittgenstein, Philosophical Investigations, I, I03. 
nevertheless adopt and pursue that project may or may not be arrogant and dogmatic, may or may not have effects on practice; it is certain that they make vitiating mistakes in their theorizing.

Oakeshott's and Wittgenstein's views of what theory cannot do for practice, then, rest on affirmations not denials, on what they believe to be warranted conclusions, not on skepticism about the possibility of such conclusions. The same is true of the more constructive possibilities for theory which, despite their official disclaimers, are opened up by their theories of theory and practice.

There is a world of ideas that is and is known to be (partly) coherent, a form of life that is "in order." Thinking within that world or form of life and by its criteria of coherence and incoherence, order and disorder, theorists attempt to identify confusions and inconsistencies and thereby to enlarge (at least in the sense of restoring) order and coherence. In doing so they are of course liable to make mistakes. The more important point is that the wherewithal for identifying mistakes as such and for correcting them is provided (to all participants not only or distinctively to philosophers and theorists) by the world of ideas or the form of life. This conception of philosophy and theory is confined in ways that will make it unwelcome to some liberals, but it is affirmative not skeptical.

In disqualifying on philosophical grounds the soaring, self-promoting aspirations of some moral and political philosophers, Oakeshott and Wittgenstein buttress recurrent if unsteady tendencies in liberalism. Let us now consider affinities between some other persistent (but also unsteady) liberal propensities and the more constructive possibilities that are licensed by the positions of these two nonliberal thinkers. In making these comparisons I restrict my remarks to one of a number of possibilities, namely, the notion of "respect," first as in "a decent respect for the opinions of mankind" and second in the sense in which many liberal theories (perhaps especially nonempiricist theories) strongly promote "respect for persons" and arrangements that sustain and enhance "self-respect."

For Jefferson and his fellow signers, respect for the opinions of humankind was a moral and political imperative. Of course the imperative did not require them to agree with or accede to the opinions of others. The signers of the Declaration discharged this among their duties by taking seriously the opinions of humankind-by trying to understand opinions other than their own, by 


\section{Toward a Liberalism}

explaining their own views to others, and by attempting to justify their actions in ways responsive to objections and disagreements. Self-respect and respect for persons are more complex and perhaps more elusive notions, but no one would say that they require accepting the beliefs and values of all those to whom respect is owed or whose self-respect one is trying to sustain and enhance. Serious, perhaps sympathetic, consideration is due, but conflicts among the beliefs and values of persons make agreement with all of them impossible, and in many circumstances the duty itself is thought to require attempts to correct the mistaken or ill-considered views of those to whom respect is owed.

Neither these imperatives nor the concepts in which they are expressed make any appearances in Wittgenstein's thought, and they appear in Oakeshott's, if at all, in a diction quite different than those usual in liberalism. But if "a decent respect" and respect for persons consist in the elements I just sketched, it is clear that a commitment to something akin to them is entailed by those of Wittgenstein's and Oakeshott's views which I have emphasized in this essay.

Recall Oakeshott's rebuke to theoreticians for dismissing the thinking of practitioners as "worthless nescience" and Wittgenstein's view that those who do "what used to be called philosophy" fall into confusion because they refuse to give close attention to "the language of every day." To dismiss, to refuse to take seriously, the thinking and acting of practitioners is to dismiss elements of experience and reality themselves. Whatever effects doing so may have on practice and practitioners, it guarantees the failure of philosophy and theory.

Here again Oakeshott and Wittgenstein, qua practitioners, are not therefore committed (or, as it happens, particularly disposed) to agree with the beliefs, opinions, and practical judgments of other practitioners - no more so than Jefferson and his colleagues committed themselves to agree with the opinions of all of humankind about American independence, Kant with Roman Catholics, Green with the pro-alcohol lobby, or Rawls with those who reject religious toleration. Qua philosopher or theorist, however, Wittgenstein, Oakeshott, and anyone who accepts their philosophical positions must "take seriously," must seek to grasp the coherence and incoherence, the order and disorder, of the thinking and acting in which beliefs and opinions are embodied and expressed. 
For reasons having to do with "practical reasoning" and with which I will conclude, "respecting" thought and action, thinkers and actors, in this sense will not itself guarantee Kantian respect for persons, the self-respect of persons as Rawls and others have construed that notion, or any other moral or political achievement. But if, contrary to Oakeshott's and Wittgenstein's official view, general philosophical positions are nevertheless pertinent to practice, the position I have attributed to them is promising in this regard-more promising than the positions of liberals whose theories feature respect and self-respect as moral and political imperatives and desiderata.

In much liberal thought, the notion "person" bears little resemblance to either the Oakeshottian concept of "practitioner" or to Wittgenstein's characterizations of participants in language games and forms of life. As Oakeshott would put it, the "persons" of liberal theory are, by intention, abstract not concrete; they are described in ways deliberately chosen to eliminate the effects of traditions, conventions, and rules, shared languages, beliefs, and values. In Wittgensteinian parlance, these "persons" are not understood as parts of "wholes" such as language games and forms of life. Treated as "atomic entities," as denizens of "states of nature" or parties to "original positions" veiled in ignorance, they are abstracted from the "mechanisms" in which they can be "somethings" rather than "anythings" or "nothings." 36 These differences stand out in yet bolder relief when we look at the attempts of leading liberal theorists to give content to the ideas of respect, regard, and consideration. Respecting persons and contributing to their selfrespect are made to consist in protecting their "natural rights," fostering their "self-realization," or contributing to their "full autonomy." Rather than looking within the traditions and conventions of actual societies to see what their members regard as showing respect and disrespect (looking, for example, at the conventions of polite conduct, the forms of address, of demeanor, of gift and return of gift, and the like), liberal theorists set such considerations aside in favor of criteria that, they argue, deserve acceptance and implementation whether or not they accord with already accepted norms and expectations. The objective of devotees of these notions is to resolve conflicts among and otherwise to improve on the think-

36Ibid., I, 6. 


\section{Toward a Liberalism}

ing and acting of practitioners. Thus natural rights must be protected even if their putative bearers find the idea of such rights incomprehensible or the measures proposed to protect them strongly objectionable. Again, views about self-realization, autonomy, and like notions that conflict with the theory-generated criteria that properly govern them, however widely accepted those views might be, are to be given no weight in moral and political deliberation.

To the extent that these (admittedly casual and underdefended) characterizations of theories of respect and self-respect are accurate concerning identifiable liberal thinkers, ${ }^{37}$ they support my earlier suggestion that non- and antiempiricist liberals are prone to conceptions of theory and practice at odds with the theory of theory and practice I have attributed to Oakeshott and Wittgenstein.

Of course a detailed defense of this suggestion would not discredit the moral and political substance of these theories-no more so than refutations and dissolutions of empiricism discredit the specifically moral and political proposals of self-styled empiricist liberals such as Mill and Russell. If, per impossible on Oakeshott's and Wittgenstein's theory of theory and practice, a "theory" were formed or a "proposal" advanced which was genuinely independent of practice, which owed nothing to practitioner understandings, "it" would discredit itself in the deep sense that it would be unintelligible (including to its proponent).

This comment may explain why Oakeshott insists and Wittgenstein sometimes suggests that philosophy and theory in their senses are irrelevant to practice. Because all theories in other senses, and all proposals, must satisfy the Oakeshottian criteria of intelligibility and the Wittgensteinian criteria of meaningfulness, those criteria cannot discriminate among theories or proposals. And because those criteria are all that philosophy and theory in their senses provide, philosophy and theory are irrelevant to practice.

Even if strictly correct as regards philosophy and theory in the most insistently circumscribed construals I have considered, this position underestimates their prophylactic value to practice. To the extent that Oakeshott's and Wittgenstein's theories of theory and practice are accepted, practice is protected against the claims, com-

37I will not attempt to document the characterizations here. Thinkers to whom I think they apply are Ronald Dworkin on the notion of respect generally, T. H. Green on self-realization, Kant on autonomy, Alan Gewirth on natural rights, John Rawls on self-respect and "full autonomy." 
monplace in our civilization and culture, of "theoreticians" and proponents of "what used to be called philosophy" to the authority to dictate to all other practitioners. (Those persuaded by my discussion of liberalism and authority in Chapter 2 might agree that at least in this regard the views of Oakeshott and Wittgenstein are congenial to liberalism.)

We have seen reason to say more than this. If practice itself is "theorylike," we need distinctions within theory and philosophy as well as between them and practice, and we cannot get along with one distinction between theory and practice. One possibility is to say that philosophy is concerned with the criteria of intelligibility or meaningfulness as such and therefore has no more (but no less) than prophylactic value for practice (a stipulation for which there is warrant in Oakeshott's own distinction between philosophy and theorizing). Theory, then, will be the attempt to discern and enhance the intelligibility (coherence) or meaningfulness of this or that practice or language game, these or those performances of particular practitioners or participants. Insofar as theorists succeed in such attempts, they may contribute something of value to practice and to practitioners. This distinction, drawn as it is in terms of differences in purposes or objectives, all of which are pursued within the world of ideas or within forms of life, cannot be categorial in Oakeshott's sense; but it is no less valuable for that.

With this distinction in hand we can discern an understanding of great importance in Oakeshott's and Wittgenstein's otherwise exaggerated assertions that theory is irrelevant to practice. Theory in the sense just distinguished is integral to practice and hence to practical reasoning or judgment. As delineated and elaborated in Oakeshott's and Wittgenstein's theories of theory and practice, however, theory itself can never bring practitioners all the way to the practical conclusions necessary to action. This is not because theory and theorizing must be superseded by "will," "decision," or some kind of "leap" that is to be understood (if at all) in terms of impulses, inclinations, or some other characteristics that owe nothing to the traditions and practices, language games and forms of life in which they occur. As with all "exhibitions of intelligence,"38 judgment, decision, and action are possible only in traditions and practices, language games and forms of life. Rather, it is because theory and theorizing are always general, always concerned with classes or

${ }^{38}$ Oakeshott, On Human Conduct, p. 13. 


\section{Toward a Liberalism}

categories and the relations among them, whereas judgment and action are concerned with particulars. Without what I am calling theory and theorizing, particulars would be "bare" and hence "anythings" or "nothings," not "somethings." But for this very reason theory and theorizing will not themselves single out this or that particular from the class or category in which it is intelligible and hence will not carry through to action. In order to act, the theorist must become a practitioner; or as the tradition to which this dimension of Oakeshott's and Wittgenstein's thinking contributes says it, theoretical reasoning must stop and practical reasoning must begin.

We might say that the discussion of practical reasoning began when Plato argued that philosophers must become kings. Having no doubt that philosophers could arrive at the truth about morals and politics, Plato nevertheless concluded (reluctantly and regretfully) that they could make their truths effective in practice only if they became that species of practitioner known as a king. But Plato's reason for this conclusion seems to have been that only philosophers can be relied on to do in practice what the truths of theory require. Philosophers must become practitioners because of defects or deficiencies in the understanding, the rectitude, and so on of nonphilosophers, not because of any difficulty intrinsic to putting theory into practice.

By contrast, from Aristotle to Oakeshott and Wittgenstein a number of thinkers, including some who have been confident that they could discover, develop, or construct warranted general truths or principles, have argued that such truths and principles necessarily underdetermine moral and political decisions and must be supplemented by kinds of thinking and acting that may be influenced by theory but that are not themselves theoretical. Aristotle's phronesis, the scholastic doctrine of casuistry, the Kantian concept of judgment, Oakeshott's notion of pursuing the intimations of a tradition, Wittgenstein's treatment of rules, rule following, and "knowing how to go on" (perhaps the most radical of these doctrines) - all exemplify this position. According to it, claims that a general principle or set of such principles enjoin or prohibit a particular judgment or action can always be successfully rebutted; genuine commitment to a theory or theoretically derived principle is always consistent with a variety of actions; it is never possible to disqualify, exclusively by appeal to theoretical considerations, all but one decision or course of action. The difficulty is not that there 
may be slips between theoretical cup and practical lip, but that getting from cup to lip requires particularization and the abilities and skills to effect it which the theoretical cup cannot contain. ${ }^{39}$

Those parts of Oakeshott's and Wittgenstein's theory of theory and practice which I styled "philosophy" teach anew the lesson of this limitation on itself and on theory and theorizing. In doing so they do all that they can to expose and protect practice and practitioners from the pretensions and presumptions of theoreticians masquerading as theorists. As with the arguments of the earlier theorists of practical reasoning whom I mentioned, however, and despite their programmatic statements to the contrary, the Oakeshottian and Wittgensteinian theories of theory and practice give us reason not to deny or to dismiss but rather to value and to augment the contributions that good theory can make to practice.

With the possible exception of Kant, none of the theorists of practical reasoning I have mentioned in the last pages is a liberal, and it would be absurd to suggest that their theories of theory and practice entail, imply, or recommend any of the self-styled liberal moral and political theories. But if liberalism acknowledges and welcomes the variety and changeable character of moral and political practices, if it recognizes and delights in the restless diversity of moral and political practitioners, these conclusions concerning the limitations and possibilities of theory and theorizing are neither surprising nor disturbing, neither to be resisted nor regretted. More than this the theorist of theory and practice cannot and should not try to say.

${ }^{39}$ Valuable recent discussions of practical reasoning include Ronald Beiner, Political Judgment (Chicago: University of Chicago Press, I983); and Charles Larmore, Patterns of Moral Complexity (Cambridge: Cambridge University Press, 1987). 